\section{木造軸組真壁構造に用いる部材 内蔵型金物の開発と力学特性}

DEVELOPMENT AND STATIC CHARACTERISTICS OF EMBEDDED STIFFENERS FOR JOINTS OF A SHINKABE WOODEN FRAME
丸山純夫— $* 1$ 入江康隆 — $* 2$

キーワード :

部材内蔵型金物，金物の設置方法，繰り返し加力試験,

エネルギー吸収能

Keywords:

Embedded stiffener, Installation method of the stiffener, Repeated loading tests, Energy-absorbing capacity

\section{Sumio MARUYAMA — $* 1 \quad$ Yasutaka IRIE $-* 2$}

We developed an embedded stiffener for joints of Shinkabe wooden frames. This paper describes functions, installation method of this stiffener and results of repeated loading tests. The main results of these experiments are as follows.

The energy-absorbing capacity and load-bearing capacity of joints using embedded stiffeners are large compared with joints using Hagoita bolts. It is expected the embedded stiffener make Shinkabe wooden frame high-function and high-strength.

\section{1. はじめに}

在来構法の補強金物には、Zマーク表示金物の部材どうしをとめ るカスガイ、山形プレート、短冊金物と、部材を引き寄せる機能を 併せ持つ羽子板ボルトと引き寄せ金物がある。これらの金物は接合 部材の表面（側面）に取り付けるため、梁や柱を現す真壁構造に用 いると金物が現れてしまう。金物が接合部材の表面にあると、仕上 げ方法にもよるが、結露が生じやすく、かつ防火的ではない。また 接合部材の側面に取り付けると、木部材に応力の偏心が起こる。こ れらの点を改良するために、部材に内蔵可能で、強度も勒性にも優 れた金物（部材内蔵型金物と称する。以下同じ。を)開発した。この 金物は梁と梁、梁と柱、土台と柱の接合部における引張り力の補強 を目的としている。これと同様に引き寄せ機能があり引張り力を負 担する在来構法の補強金物としては羽子板ボルトがある。そこで一 般的な梁と柱の羽子板ボルトの接合部と部材内蔵型金物の接合部の 機能と力学的特徴を比較する。その結果から、木造軸組真壁構造に 用いる部材内蔵型金物の実用化の可能性を確かめる。

表 1 部材内蔵型金物と在来構法用金物との比較

\begin{tabular}{|c|c|c|c|c|}
\hline & 部材内藏型金物 & 材種 & 在来構法用金物 & 材種 \\
\hline \multirow{3}{*}{$\begin{array}{c}\text { 部品 } \\
\text { (負担応力) }\end{array}$} & SH1230（引張り） & SWCH $45 \mathrm{~K}$ & M12 羽子板ボルト (引張り) & $\begin{array}{l}\text { Zマーク表示金物 } \\
4 \mathrm{~T} \text { ボルト1 } 1 \text { 種 SPHC }\end{array}$ \\
\hline & CW12（めり込み） & S30C & M12 ボルト（曲げめり込み） & $\begin{array}{l}\text { Zマーク表示金物 } \\
4 \mathrm{~T} \text { ボル下 }\end{array}$ \\
\hline & BN1275（めり込み） & STKM13A & 座金 (めり込み) & $\begin{array}{c}\text { Zマーク表示金物 } \\
1 \text { 種 SPCC }\end{array}$ \\
\hline 引張材の取り付け & \multicolumn{2}{|c|}{ 部材軸方向の部材心の穴 } & \multicolumn{2}{|c|}{ 木部材の外面 } \\
\hline 引張力の導入方法 & \multicolumn{2}{|c|}{ CW12 の移動 } & \multicolumn{2}{|l|}{ ナットの| } \\
\hline
\end{tabular}

\section{2. 部材内蔵型金物の仕組み}

\section{1 部材内蔵型金物の部品の応力機能と取付け状況}

表 1 は、部材内蔵型金物と在来タイプ金物羽子板ボルトの、部品 の応力機能と材種を示す。写真 1 に部材内蔵型金物と写真 2 に羽子 板ボルトの取付け状況を示す。なお、写真 1.1 は部材内蔵型金物の 取付けの途中を示している。

\section{2 部材内蔵型金物の名称と仕様及びその内蔵方法}

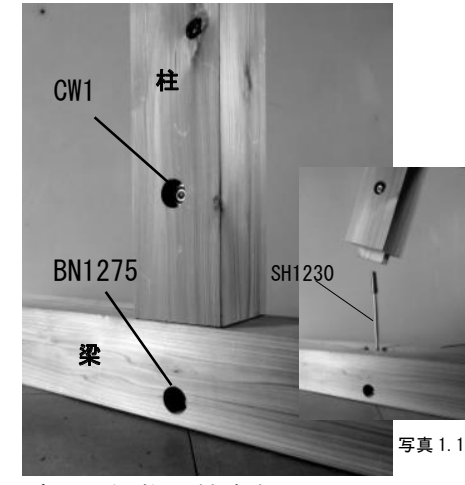

写真 1 梁柱の接合部に設置 された部材内蔵型金物

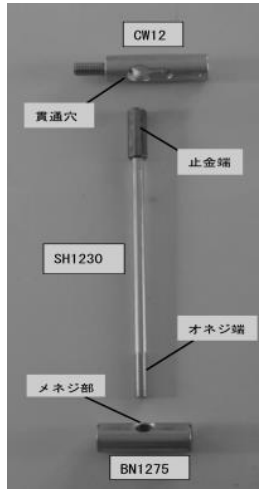

写真 3 部材内蔵型金物

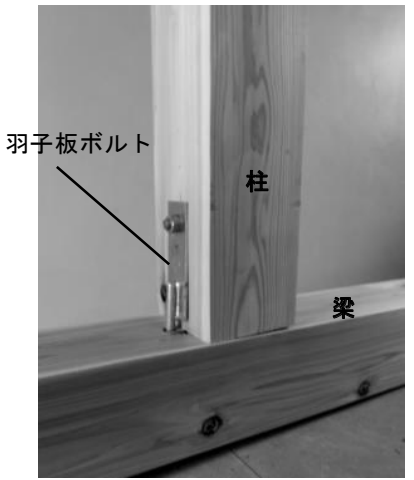

写真 2 梁柱の接合部に設置 された羽子板ボルト
表 1 の、部材内蔵型金物の部品の名称と仕様を、写真 3 と写真 4 で説明する。部品名はアルファベットで名称を示し、数字は寸法を 示している。SH1230の SH は軸を表す Shaft のことである。数字の 1230 は軸径 $12 \mathrm{~mm}$ 長さ $30 \mathrm{~cm}$ を示し「金棒」と称する。この両端部は、 写真 3 のようなオネジが加工されているオネジ端と、止金がついて

\footnotetext{
(株)ユー建築工房

( ( 326-0337 栃木県足利市島田町 151-1)

宇都宮大学 名誉教授・工博
} 
いる止金端からなる。CW12 の CW は Concea1 Wedge で数字の 12 は軸 径 $12 \mathrm{~mm}$ のSH1230 用であることを示す。この外形は円柱形で平面は 丸く、くさびと同じ引寄せ機能を有するので「丸くさび」と称する。 その側面には、SH1230を引張るための傾斜面を持つ貫通穴がある。 また、SH1230 が貫通穴から抜け出ないように押える六角穴付き止め ネジが付属している。これをロックボルトと名づける。BN1275 の BN は棒（Bou）状のナット（Nut）「棒ナット」を示す。数字の 12 は軸 径 $12 \mathrm{~mm}$ のSH1230 用であることを示し、75 は長さが $75 \mathrm{~mm}$ であるこ とを示す。この側面にはメネジが加工されている。

部材内蔵型金物の梁、柱の部材加工と金物の内蔵方法を写真 1 と 写真 3 を参照して説明する。まず、BN1275 と CW12 用の穴を梁、柱 の材側面にあける。その穴と直交する SH1230 用の穴を、梁には柱胴 付側面に、柱には柱脚端部から材軸方向に深穴をあける。梁側面の 穴にBN1275 を挿入し、その側面の加工したメネジに SH1230 のオネ ジ端をねじ込む。SH1230の止金端は、梁から突出した状態 (写真 1.1) になっている。CW12 は柱側面の穴から挿入して、柱内に納めておく。 柱を梁から突出しているSH1230の止金端を、柱脚端部の深穴に差し 入れて (写真 1.1)、柱内にある CW12 の傾斜面を持つ貫通穴に挿入 する。これで部材内蔵型金物の 3 部品は、写真 4 のような組合せで、 梁と柱に内蔵されたことになる。

\section{3 部材内蔵型金物への引張り力導入方法}

写真 5 は梁柱接合部における柱側内部での、金棒SH1230 と丸くさ びCW12 の取り合い示す。まず、写真 3 のSH1230 オネジ端を、梁内 のBN1275 のメネジにねじ込んで固定 (写真 1.1) しておく。一方の SH1230 止金端は CW12 貫通穴に貫通させる（写真 5)。次に SH1230 に引張り力を導入するときの部材内蔵型金物の状況を写真 6 と写真 7 に示す。写真 6 は引張り力導入前の写真であり、写真 7 は引張り 力導入後の写真である。なお、写真 6 は止金 $R$ 面（半球面）と丸く さび傾斜面（曲面）は点接触しているので止金が浮いているように 見える。また、写真 $6 、$ 写真 7 に示す A、B、C の説明をすると、A は SH1230止金端がCW12の傾斜面に掛かる時のロックボルトのCW12 からの出寸法であり、B は CW12 の長さの 2 等分の寸法を、C は ロッ クボルトを A だけねじ込むと $\mathrm{SH} 1230$ が引かれる寸法である。これ を踏まえて以下に引張力の導入過程を説明する。ロックボルトをね じ込んで、SH1230 止金端の止金 R 面を、CW12 の丸くさび傾斜面に掛 ける（写真 6)。さらにロックボルトを写真 7 の A だけねじ込むと、 ロックボルトの先端は SH1230の軸側面を押して（写真 7 矢印 (1) 、 CW12 は左に (写真 7 矢印(2) 引き寄せられる。この CW12 の移動に より、止金 R 面を持つSH1230 は、丸くさび傾斜面の斜め上方に移動 （写真 6,7 破線の矢印(3)）しようとする。しかし、SH1230 は柱長穴 内に拘束されて、実際には移動できない。(そのため矢印(3)を破線に している)これは丸くさび傾斜面の勾配の高さ分の写真7のCだけ、 SH1230 を上方に引く (写真 7 矢印(4) $)$ ことと同じである。この機構 により、CW12 に付属するロックボルトを締めることで、SH1230 に引 張り力が導入できる。なお、丸くさび傾斜面の勾配は、写真 5 が示 すように $15 \mathrm{~mm} / 20 \mathrm{~mm}=7.5 / 10$ であり、最大 $15 \mathrm{~mm}$ の引き代がある。ま た後締めは $15 \mathrm{~mm}-6 \mathrm{~mm}=9 \mathrm{~mm}$ が可能であり、一般的な木の乾燥収縮に 対して 3 回程度は後締めができる。また、本事例でロックボルトが CW12 にすべてねじ込まれる時に、(写真 7 の）SH1230 軸心と CW12 の中心 (写真 7 の B ) が一致する。本部材内蔵型金物は 1997 年に特
許出願をし、1999 年に特許第 2926329 号を得て、アメリカで Des. 422, 200、ドイツで第 49902686. 1 号の意匠登録をしている。

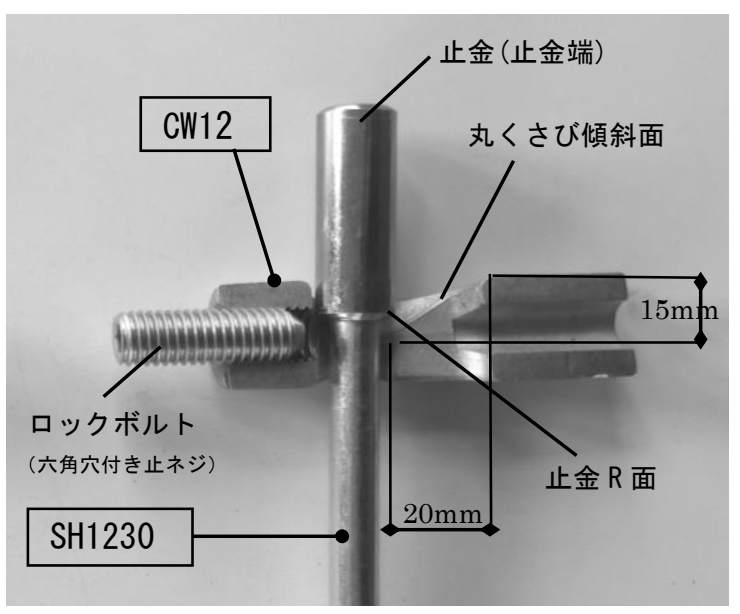

写真 5 SH1230をCW12 に挿入した時の取り合い

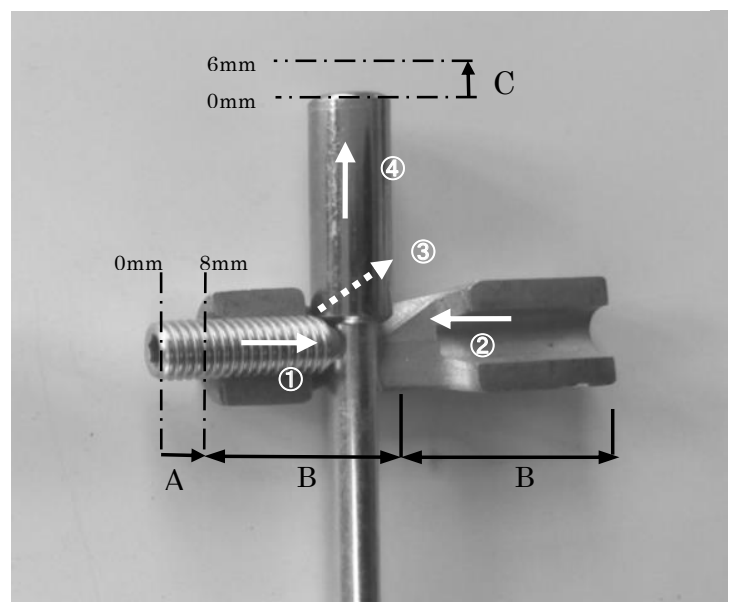

写真 6 SH1230 止金端が丸くさび傾斜面に掛かる状態

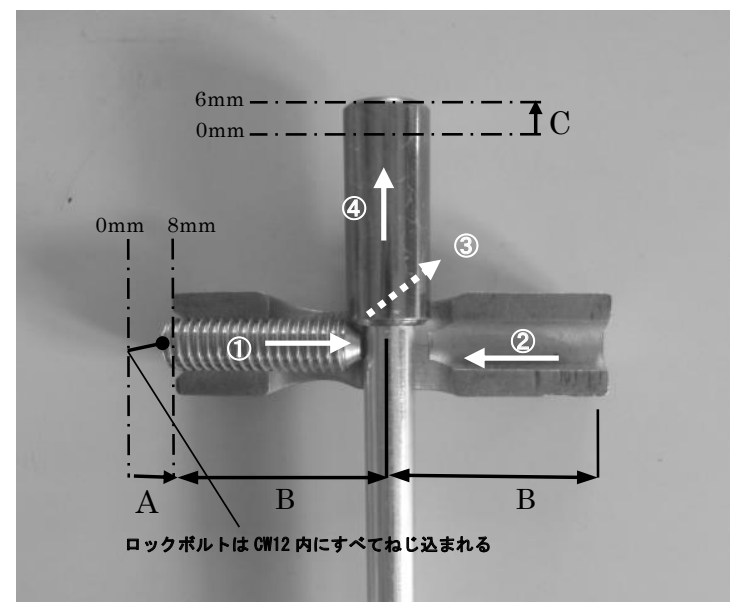

写真 7 SH1230 に引張り力を導入後の状態

\section{4 部材内蔵型金物が持つ機能と特徵}

真壁用に開発した部材内蔵型金物の特徵は次の通りである。

(1) 木部材内に内蔵可能

写真 1 は梁と柱を部材内蔵型金物で接続した取付け例である。部 材内蔵型金物の穴を木栓で塞いでいないので、部材内蔵型金物が見 える。この穴を木栓で塞げば外部からの熱橋による結露も防げる。 （2）引張り力だけを補強 
引張り力だけを補強する金物である。羽子板ボルトのように部材 側面に取り付ける金物とは違い、部材断面内中心に取り付けるので 応力の偏心が起こりにくい。なお、せん断力にはホゾ等で対応する が、加工穴による断面欠損のため負担応力が小さくなる。

(3) 部材に内蔵されても後締めできる金物

部材内蔵型金物は部材内に内蔵されても、ボルトとナットと同じ ように、部材の取付け取り外しが容易にできる。ロックボルトのネ ジに締め代の余長を持たせることで、組み立て後の木の乾燥収縮や 文献 1)に示されるクリープによる接合部の緩みを、最大 $9 \mathrm{~mm}$ まで後 締めができ、直すことが可能である。

(4) 加工よる断面欠損の極小化

写真 8 は真壁造の伝統構法の仕口である。柱に胴差が長ホゾ大入 れシャチ栓止めになっている。中央の写真 9 は在来構法の短ホゾ大 入れ全ネジボルト締めである。右の写真 10 は、開発した短ホゾ大入 れ部材内蔵型金物締めである。3 種とも継手の側面からは加工部は 見えないが、写真 8 から写真 10 行くに従い、加工による断面欠損 が小さくなっている。このように開発した部材内蔵型金物は、加工 による断面欠損を小さくできる。

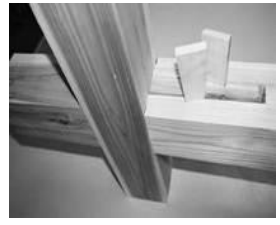

写真 8 竿シャチ栓

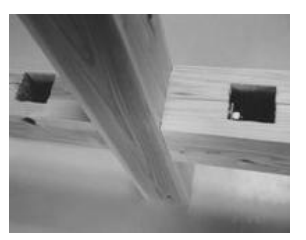

写真 9 全ねじボルト 写真 10 部材内蔵型金物
（5）一般的な在来構法と同じ加工

部材の加工は加工形状が円形のため、市販のドリルを用いる羽子 板ボルトの穴加工と同じにできる。またプレカット工場でも加工が 可能である。

\section{3. 部材内蔵型金物を使用した接合部の各種試験とその結果}

\section{1 丸くさび CW12 の設置位置が接合部強度に及ぼす影響}

丸くさび CW12 を埋め込む位置は、部材の耐力と破壊形式に影響を 及ぼすと考えられる。また、ドリルの長さの制約による施工上の理 由から、丸くさびCW12 は材端からあまり遠い位置には設けられない。 そこで丸くさびCW12 の加工穴位置をパラメータにして、部材接合部 の強度と加工穴位置との関連を求めた。材種は米松集成材、米松、 ヒバ、スギの無等級材である。

\section{(1) 試験方法}

試験装置と試験体を図 1 に示す。試験体は長さ $570 \mathrm{~mm}$ 断面 $115 \mathrm{~mm}$ $\times 115 \mathrm{~mm}$ である。その両端から、試験体側面の $60,100,120,140$, 160, 180, mm の位置（図 1 の）に、丸くさびCW12 を差し入れる穴を

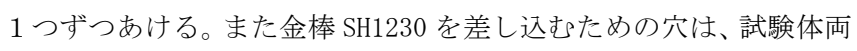
端面の中心に材軸方向の深穴をあける。試験体は各樹種とも $\ell$ =180, 160, 140, $120 \mathrm{~mm}$ は 各 10 体で $\ell=100,60 \mathrm{~mm}$ は各 3 体である。部 材内蔵型金物の設置は、2.2 節で説明した方法で行う。部材両端か ら突出させた SH1230 を、100kN の万能試験機のチャックで挟む。加 力方法は文献 3) の試験方法に基づき、単調引張り載荷で最大荷重を 超えたら最大荷重の $80 \%$ までとした。計測量は SH1230 の伸びと 1 対 の丸くさびCW12 の木のめり込みの合計の変位である。

\section{(2) 試験結果}

表 2 に文献 2) から抜粋した丸くさび設置位置が $\ell=100 \mathrm{~mm} 60 \mathrm{~mm}$ は除 $<10$ 体の試験結果の平均値を示す。荷重変位曲線が最大荷重に達し てないように見えるのは、文献 2)で示された図がこのようになって いるためである。図 2 は表 2 のスギの丸くさび設置位置を材端から l=160mm にした 10 体と、表 2 に示していないが丸くさび設置位置が 材端から $l=60 \mathrm{~mm} の 3$ 体の試験結果による $\mathrm{P}-\delta$ 曲線の平均を示す。
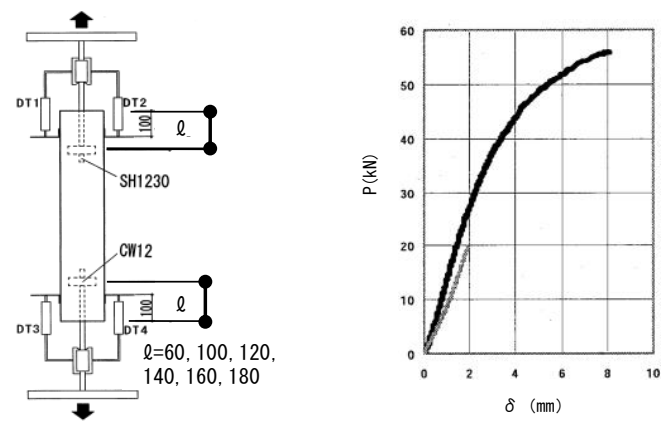

図 1 試験装置と試験体

図 2 スギ使用時部材内蔵金物の設置位置 (上 : $160 \mathrm{~mm}$, 下 : $60 \mathrm{~mm})$ の荷重変位曲線の違い

表 2 丸くさびCW12 の設置位置の違いによる試験結果

\begin{tabular}{|c|c|c|c|c|c|c|c|c|}
\hline $\begin{array}{c}\text { 樹種 } \\
\text { 等級 } \\
\text { めり込み基準強度 } \\
\text { 平均密度 } \\
\text { 平均含水率 }\end{array}$ & \begin{tabular}{|c|} 
内蔵 \\
金物 \\
の加 \\
工穴 \\
位置 $\ell$ \\
$(\mathrm{mm})$ \\
\end{tabular} & 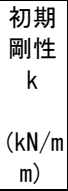 & $\begin{array}{c}\text { 降伏 } \\
\text { 耐力 } \\
\text { Py } \\
\\
(\mathrm{kN})\end{array}$ & $\begin{array}{l}\text { 降伏 } \\
\text { 変位 } \\
\delta \mathrm{y} \\
\\
(\mathrm{mm})\end{array}$ & $\begin{array}{l}\text { 最大 } \\
\text { 荷重 } \\
\text { Pmax } \\
\\
(\mathrm{kN})\end{array}$ & 2/3Pmax & $\begin{array}{l}\text { ばらつ } \\
\text { き係数 }\end{array}$ & $\begin{array}{c}\text { 短期基 } \\
\text { 準耐力 } \\
\mathrm{T}_{0} \\
\\
(\mathrm{kN})\end{array}$ \\
\hline \multirow{4}{*}{$\begin{array}{c}\text { 米松集成材 } \\
\text { E170-F495 } \\
9 \mathrm{~N} / \mathrm{mm} \\
0.52 \mathrm{~g} / \mathrm{mm}^{3} \\
15 \%\end{array}$} & 180 & 12.70 & 34.85 & 2. 77 & 56.48 & 37.66 & 0.847 & 29.55 \\
\hline & 160 & 13.16 & 35.93 & 2. 80 & 58.06 & 38.71 & 0.842 & 30.26 \\
\hline & 140 & 12.85 & 35.61 & 2.82 & 56.06 & 37.37 & 0.692 & 24.65 \\
\hline & 120 & 14.52 & 25.87 & 1.93 & 43.22 & 28.81 & 0.607 & 15. 78 \\
\hline \multirow{4}{*}{$\begin{array}{c}\text { 米松 } \\
\text { 甲種 } 1 \text { 級 } \\
9 \mathrm{~N} / \mathrm{mm}^{\mathrm{m}} \\
0.53 \mathrm{~g} / \mathrm{mm}^{3} \\
23 \% \\
\end{array}$} & 180 & 11.99 & 33.80 & 3.17 & 55.40 & 36.94 & 0.767 & 25.93 \\
\hline & 160 & 12.58 & 33.94 & 2.76 & 55.23 & 36.82 & 0.831 & 28.21 \\
\hline & 140 & 11.69 & 34.51 & 2.92 & 54.98 & 36.65 & 1.000 & 34.51 \\
\hline & 120 & 12.17 & 33.93 & 2.85 & 52.58 & 35.05 & 0.776 & 26.35 \\
\hline \multirow{4}{*}{$\begin{array}{c}\text { ヒバ } \\
\text { 甲種 } 1 \text { 級 } \\
7.8 \mathrm{~N} / \mathrm{mm}^{\circ} \\
0.47 \mathrm{~g} / \mathrm{mm}^{3} \\
23 \%\end{array}$} & 180 & 10.24 & 37.05 & 3.73 & 52.83 & 35.22 & 0.756 & 26.63 \\
\hline & 160 & 11.04 & 38. 04 & 3.50 & 55.27 & 35.84 & 0.638 & 24.51 \\
\hline & 140 & 12.67 & 34.51 & 2.92 & 50.27 & 33.57 & 0.488 & 16.39 \\
\hline & 120 & 10.64 & 33.98 & 3.25 & 51.43 & 34. 29 & 0.563 & 19.15 \\
\hline \multirow{4}{*}{$\begin{array}{c}\text { スギ } \\
\text { 甲種 } 1 \text { 級 } \\
6 \mathrm{~N} / \mathrm{mm}^{2} \\
0.44 \mathrm{~g} / \mathrm{mm}^{3} \\
41 \% \\
\end{array}$} & 180 & 8.60 & 26.12 & 3. 43 & 44.54 & 29.69 & 0.801 & 20.93 \\
\hline & 160 & 10.87 & 34.09 & 3.27 & 52.30 & 34.86 & 0.620 & 21.14 \\
\hline & 140 & 9.53 & 28.58 & 3.29 & 46.59 & 31.06 & 0.530 & 15.17 \\
\hline & 120 & 8.08 & 27.29 & 3.68 & 41.48 & 27.65 & 0.667 & 18. 22 \\
\hline
\end{tabular}

この表 2 から以下のことが分かった。

(1) 接合される木部材の樹種及び材端からの丸くさび設置位置に より、短期基準耐力は異なる。

(2) 米松集成材の短期基準耐力は、スギ無等級材より 5 割程高い。

(3) 短期基準耐力の最大值は、ヒバを除くと、丸くさびを材端から $160 \mathrm{~mm}$ 離した場合が最も大きい。

(4) 多用するスギ材においては、丸くさびを材端部から $160 \mathrm{~mm}$ に設 置した場合の短期基準耐力は $21 \mathrm{kN}$ である。

(5) 破壊形式は、樹種、丸くさび設置位置に関わらず、丸くさび穴 から材端への繊維方向の割裂であった。

以上の結果から、材端から丸くさび設置位置は、耐力および施工 上（ドリルの長さ）から $140 \mathrm{~mm}$ 以上 $180 \mathrm{~mm}$ 以内とすれば、実用上支 
障がないことが分かった。

\section{2 仕口接合部試験体の試験方法と試験結果及びその考察 (1) 試験方法}

部材内蔵型金物を使用した仕口（部材内蔵型金物仕口、以下同じ） 接合部の試験装置と試験体を図 3 に示す。試験体数は 6 体と予備試 験体 1 体の計 7 体であり、材種は無等級のスギ（平均密度 $0.47 \mathrm{~g}$ / $\mathrm{mm}$ 、平均含水率 $24.2 \%$ ) である。試験体の部材寸法は、柱が長さ $600 \mathrm{~mm}$ （短ホゾ長さ $24 \mathrm{~mm} \times$ 幅 $40 \mathrm{~mm} \times$ 幅 $40 \mathrm{~mm}$ ） 梁は長さ $700 \mathrm{~mm}$ である。断 面は両方とも $120 \mathrm{~mm} \times 120 \mathrm{~mm}$ である。なお、丸くさび $\mathrm{CW} 12$ の設置位 置は、3.1 節の結果を参考にして、図 3 に示寸ように、柱の材端か ら丸くさび CW12 までの端あき $150 \mathrm{~mm}$ と、BN1275 の設置位置は梁上 面から縁あき $90 \mathrm{~mm}$ の所である。試験体の設置は、柱を加力治具とボ ルトM16を 8 本でとめた。梁は PC 鋼棒 $(\phi 17)$ で固定した鋼製土台に ボルト 2-M16 座金 $\mathrm{t} 12 \times 100$ ロで取付けた。柱の上部は治具に PC 鋼棒 ( $\phi 17)$ を取り付けて、先端のナットとオイルジャッキの間に球座お よびロードセルを配置した。計測は柱と梁の試験体に取り付けたア ルミアングルに、変位計のスピンドルを接触させて行う。加力方法 は $100 \mathrm{kN}$ の試験機を用い、文献 3)の方法に基づいて行った。

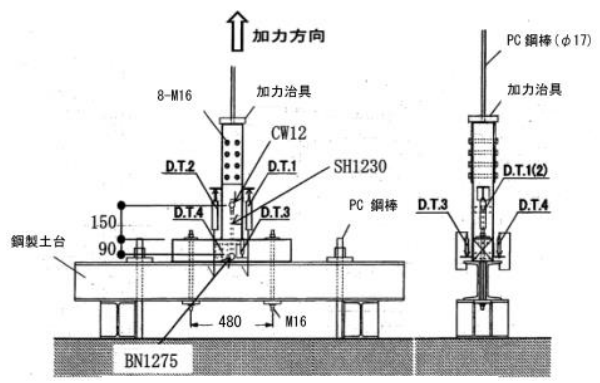

図 3 試験装置と試験体

なお、予備試験は単調引張り載荷を行い、本試験は一方向繰返し 引張り載荷とした。一方向繰返し引張載荷は、予備試験体で得られ た降伏耐力 $\mathrm{P}_{\mathrm{y}}$ 時の変位 $\delta \mathrm{y}$ の、1/2, 1, 2, 4, 6, 8, 12, 16 倍の変位を目 標にして、順に各 1 回の変位制御加力とした。なお、羽子板ボルト (表 1 のマーク表示金物 SB-F) を使用した在来構法タイプ仕口(羽 子板ボルト仕口、以下同じ）の接合部試験体の力学特性と比較する ため、文献 4）に示された羽子板ボルト仕口の接合部試験体（断面 寸法 $105 \mathrm{~mm} \times 105 \mathrm{~mm}$ ）の試験結果を引用する。この試験結果も文献 3) に基づく試験によるものである。しかし、試験体の寸法が異なるの で、補正した復元力特性の傾向を比較する。

\section{(2) 試験結果}

部材内蔵型金物仕口の接合部試験体 6 体の荷重変位曲線と羽子板 ボルト仕口の接合部試験体 3 体 (文献 4) の平均荷重変位曲線を図 4 に示寸。図 4 の部材内蔵金物の荷重変位曲線は、試験体 6 体の各々 の平均を示し、それに示寸試験体番号は表 2 の試験体番号と同じも のである。またN No.1 №.6の 6 種の平均の荷重変位曲線を破線で示す。 部材内蔵型金物仕口と羽子板ボルト仕口の試験体は、柱と梁の断面 寸法が異なり、そのままでは比較できないため、部材の断面寸法を 補正して同じにした。羽子板ボルト仕口の接合部の耐力は文献 5) p30 式 (6.4) 降伏せん断耐力と比例するとして、降伏せん断耐力 が最大となる破壊形式による接合形式係数 C=1 とすれば、取付けボ ルトが柱の穴内に接する長さりに比例する。それは柱幅の比 $120 \mathrm{~mm} /$ $105 \mathrm{~mm}=1.14$ 倍にした值になる。図 4 の荷重変位曲線の最下位の柱幅

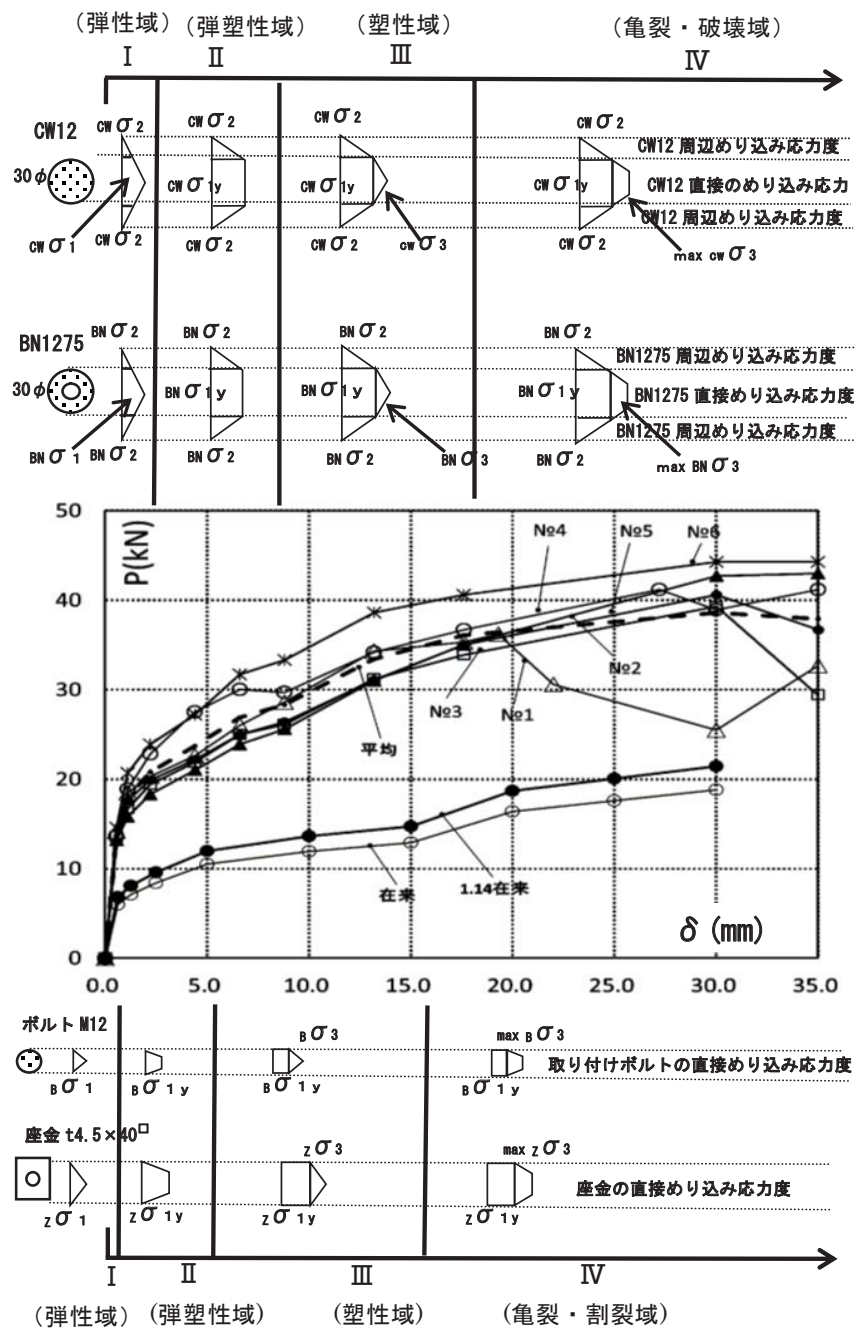

図 4 部材内蔵型金物仕口の接合部試験体と

羽子板ボルト仕口の接合部試験体の荷重変位曲線

表 3 部材内蔵型金物仕口の接合部試験体の試験結果

\begin{tabular}{|c|c|c|c|c|c|c|c|c|}
\hline \multicolumn{2}{|c|}{ 試験体番号 } & \multirow{2}{*}{\begin{tabular}{|c|} 
予備 \\
18.9 \\
\end{tabular}} & \multirow{2}{*}{\begin{tabular}{l|} 
No.1 \\
18.2
\end{tabular}} & \multirow{2}{*}{\begin{tabular}{|l|} 
No.2 \\
18.9 \\
\end{tabular}} & \multirow{2}{*}{\begin{tabular}{l|} 
No.3 \\
19.3
\end{tabular}} & \multirow{2}{*}{\begin{tabular}{|l|} 
No.4 \\
24.1 \\
\end{tabular}} & \multirow{2}{*}{\begin{tabular}{|c|}
$\mathrm{N} 0.5$ \\
19.4 \\
\end{tabular}} & \multirow{2}{*}{\begin{tabular}{|l} 
No.6 \\
23.6
\end{tabular}} \\
\hline Py & $(\mathrm{kN})$ & & & & & & & \\
\hline Py ave. & $(\mathrm{kN})$ & & \multicolumn{6}{|c|}{20.6} \\
\hline 変動係数 & & & \multicolumn{6}{|c|}{0.126} \\
\hline ばらつき係数 (V) & & & \multicolumn{6}{|c|}{0.709} \\
\hline Py ave. $\times V$ & $(\mathrm{kN})$ & & \multicolumn{6}{|c|}{14.6} \\
\hline $2 / 3 P \max$ & $(\mathrm{kN})$ & 24.7 & 24.2 & 28.5 & 26.2 & 27.4 & 27.1 & 29.6 \\
\hline 2/3Pmax ave. & $(\mathrm{kN})$ & & \multicolumn{6}{|c|}{27.2} \\
\hline 変動係数 & & & \multicolumn{6}{|c|}{0.069} \\
\hline ばらつき係数 (V) & & & \multicolumn{6}{|c|}{0.839} \\
\hline 2/3Pmax ave. $\times V$ & $(\mathrm{kN})$ & & \multicolumn{6}{|c|}{22.8} \\
\hline 短期基準耐力 (T0) & $(\mathrm{kN})$ & & \multicolumn{6}{|c|}{14.6} \\
\hline$P \max$ & $(\mathrm{kN})$ & 37.1 & 36.2 & 42.7 & 39.3 & 41.2 & 40.6 & 44.3 \\
\hline$k$ & $(\mathrm{kN} / \mathrm{mm})$ & 17.5 & 18.8 & 8.2 & 9.7 & 9.5 & 11.1 & 11.9 \\
\hline$\delta \mathrm{y}$ & $(\mathrm{mm})$ & 1.1 & 1 & 2.3 & 2 & 2.5 & 1.7 & 2 \\
\hline$\delta \max$ & $(\mathrm{mm})$ & 22.2 & 19.3 & 30 & 30 & 27.2 & 30 & 30 \\
\hline \multicolumn{2}{|c|}{ 破壊形式 A:柱の割裂 B:梁の引き裂け } & $\mathrm{A}$ & $\mathrm{A}$ & $\mathrm{A}, \mathrm{B}$ & $\mathrm{A}, \mathrm{B}$ & $\mathrm{B}$ & $\mathrm{B}$ & $\mathrm{A}, \mathrm{B}$ \\
\hline \multicolumn{2}{|c|}{ 割裂状況 $\quad S: 1$ 面割裂 W: 2 面割裂 } & $\mathrm{S}$ & $\mathrm{s}$ & $\mathrm{S}$ & $\mathrm{S}$ & - & - & W \\
\hline
\end{tabular}

$105 \mathrm{~mm}$ の在来のグラフを 1.14 倍にしたものが、下から 2 番目の 1.14 在来のグラフである。なお、図 4 から得た部材内蔵型金物仕口の耐 力と変形性能を表 3 に示す。この表からばらつき係数を考慮した部 材内蔵金物仕口の短期基準耐力は $14.6 \mathrm{kN}$ であり、羽子板ボルト仕口 
は文献 4)から $7.5 \mathrm{kN}$ である。この図から、各試験体は変位 $1 \sim 2 \mathrm{~mm}$ で降伏し、その後荷重は漸増していることが分かる。漸増している 荷重変位関係が、どのように生じていくかを考察したのが、図 4 の 上（部材内蔵型金物仕口によるもの）と下（羽子板ボルト仕口によ るもの）に示す応力度分布の模式図である。図 4 上下の図について の考察は、この後の (3) 考察で詳述する。また、これらの応力度が、 両仕口に使用されている金物により、どのような機構で生じたもの かを示したのが図 5 である。部材内蔵型仕口においては、図 5 左に 示すようにCW12 と BN1275 の木部へのめり込みと SH1230の引張りで 外力に抵抗する (文献 6)。羽子板ボルト仕口は、取り付けボルトM12 の木部へのめり込み、羽子板ボルトの座金の木部へのめり込みと羽 子板ボルトの引張りで外力に抵抗する（文献 7 )。
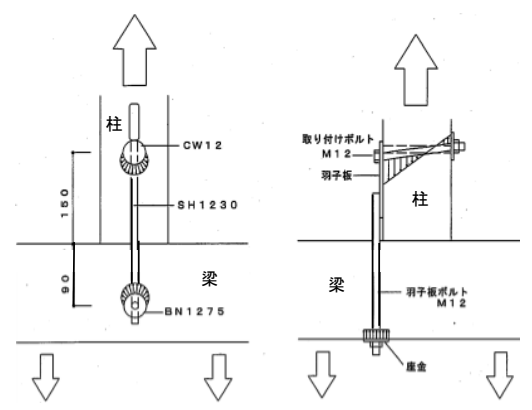

図 5 部材内蔵型金物仕口（左）と羽子板ボルト仕口（右） の作用応力模式図

\section{(3) 考察}

図 5 に示した接合部が引張られた場合、鋼材（図 5 左 : SH1230、 図 5 右 : 羽子板ボルト) 一の引張りと共に、木部内の金物による木 部へのめり込みが生じる。図 4 に示した荷重変位曲線は、これらの 接合金物の木部一のめり込み応力度の推移（図 4 の上下に示した模 式図）により特徴付けられると考えられる。すなわち、荷重変位曲 線の変曲点位置を境にして、図 4 上下に示すように I (弹性域) と II （弾塑性域）III（塑性域）IV（亀裂・割裂域）に分けられる（文献 8）と考えられる。その時の部材のめり込み応力度(加力方向だけの 成分)の状態で、めり込み途中の応力度を三角形で示し、降伏応力度 は台形で、完全に降伏したときのめり込み応力度は矩形の模式図と して表す。また、文献 7) 文献 8)により、木部材のめり込み応力度は 金物が直に接するめりこみ応力度と、金物周辺のめり込み応力度か らなるとし、図 5 の作用応力の模式図のように、木部材の繊維方向 と金物の接触状態（縦圧縮か横圧縮か）により、金物周辺のめり込 み応力度の可否、あるいは木部材の許容するめり込み降伏応力度は 異なる。文献 8)によれば、スギ材の、部材内蔵型金物 CW12 と羽子 板ボルトの取り付けボルトは、繊維方向と接触する部分圧縮（縦圧 縮）であり、その圧縮基準強度は $\mathrm{F}_{\mathrm{C}}=17.7 \mathrm{~N} / \mathrm{mm}^{2}$ である。この縦圧縮 は、金物直によるめり込み応力度だけと考えられる。しかし、部材 内蔵型金物 CW12 の断面は太い円形 $(30 \phi)$ のため、文献 6)に示され る図 5 左のような放射状のめり込み応力度になり、試験の観察から も金物周辺のめり込み応力度と塑性に伴うひずみ硬化も生じると推 定する。しかし羽子板ボルトの取り付けボルトは、軸径 (M12)が細い ため、金物が直に接するめり込み応力度だけで、金物周辺のめり込 み応力度の影響は少ないと考える。また、部材内蔵型金物 BN1275 と羽子板ボルトの座金は、繊維直交方向の材中間部の部分圧縮（横
圧縮）になり、その基準材料強度は $\mathrm{F}_{\mathrm{CV}}=6.0 \mathrm{~N} / \mathrm{mm}^{2}$ である。なお、各 金物と木部材との接触面積は、部材内蔵型金物では、金物外形面積 から金棒 SH1230 の穴(径 $21 \phi$ ) の面積を差し引いて算定すると、 CW12 は $2178(=(30 \times 90)-(10.5 \times 10.5 \times 3.14+11.6 \times 11.6+5.5 \times 5.5 \times 3.14))$ mnにになり、BN1275 では $1903(=(30 \times 75-10.5 \times 10.5 \times 3.14))$ m!nにになる。 また、羽子板ボルトでは、取り付けボルトは $1440(=12 \times 120) \mathrm{mm}^{2}$ 座金 は $1600(=40 \times 40) \mathrm{mm}^{2}$ である。

\section{a) 部材内蔵型金物仕口の場合}

I (弾性域)では金物と木部材は緩みなく接触しているため、図 4 の荷重変位曲線の変位と耐力は零から始まっている。I (弾性域)の めり込み応力度は文献 6)によると、図 5 左 のような木部材のめり 込み応力度が生じて、図 4 の上部に示す部材内蔵型金物 BN1275 と、 $\mathrm{CW} 12$ の金物が直に接するめり込み応力度 ${ }_{\mathrm{BN}} \sigma_{1 、 \mathrm{CW}} \sigma_{1}{ }_{1}$ と、金物の周 辺部分のめり込み応力度 ${ }_{\mathrm{BN}} \sigma_{2, \mathrm{CW}} \sigma_{2}$ と表せる。 II (弾塑性域) では、 BN1275 は部材の基準材料強度と金物接触面積が CW12 より小さいた め、BN1275 の金物に直のめり込み応力 ${ }_{\text {BN }} \sigma{ }_{1}$ は先にめり込み降伏応 力度 ${ }_{\text {BN }} \sigma_{1} \mathrm{y}$ に至る。さらに加力が進むと、CW12 が直に接する部分 のめり込み応力度 $\mathrm{CW} O{ }_{1}$ が増大し、めり込み降伏応力度 $\mathrm{CW} \sigma{ }_{1} \mathrm{y}$ を示 す。この時が I (弾性域)と II (弹塑性域) の境界のめり込み応力度 である。これは表 3 における降伏耐力 $\mathrm{Py}=20.6 \mathrm{kN}$ であり、算定した 平均の変位 $\delta \mathrm{y}=1.9 \mathrm{~mm}$ である。III（塑性域）では、文献 8) が示すよ うに、CW12 のめり込み降伏応力度 $\mathrm{CW}^{\sigma} \sigma_{1} \mathrm{y}$ にひずみ硬化による応力 $\sigma_{3}$ が加わる。IV (亀裂・割裂域) では、ひずみ硬化は最大応力度 $\max \sigma_{3}$ になり、試験の観察から変位 $\delta=18 \mathrm{~mm}$ 前後で亀裂が発生し始 める。その後は木部材が破壊するまで変位 (亀裂) は進展して行く。

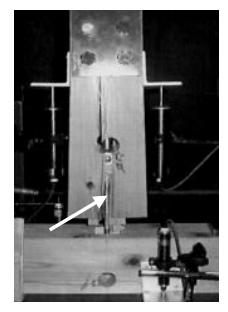

A : 柱の 1 面割

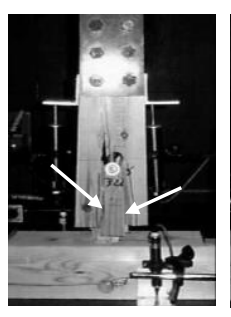

$\mathrm{A}$ : 柱の 2 面割

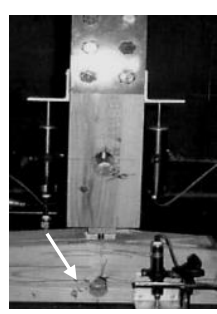

B : 梁の引き裂け
写真 11 部材内蔵型金物仕口の接合部試験体の破壊

破壊形式は写真 11 のように木部材の繊維方向の A : 柱の割裂ある いはB：梁の引き裂けである。破壊形式が A, B の一方に偏らず生じ ているのは、図 5 左の部材内蔵型金物仕口が示すように、CW12 穴の 柱の端あき $150 \mathrm{~mm}$ と BN1275 穴の梁の縁あき $90 \mathrm{~mm}$ の寸法が適正であ ったと考える。表 3 に示寸柱の割裂状況は、写真 11 の矢印のように $\mathrm{S}: 1$ 面割裂と W $: 2$ 面割裂があり、2 面割裂時の耐力と最終破壞まで の変形量が 1 面割裂時のそれらよりも大きい。なお、金物と木部材 との接触面積は、繊維方向で部材内蔵型金物 CW12 の方が、羽子板 ボルトの取り付けボルトより $50 \%$ ほど大きく、繊維直交方向は、部 材内蔵型金物 BN1275 が、羽子板ボルトの座金よりも20\%ほど大きい。 部材内蔵型金物は、この接触面積の大きさを有して、木部材のめり 込みを生かしていると言うことができる。

\section{b）羽子板ボルト仕ロの場合}

文献 8)を参考にすれば、取り付けボルトの軸径 (12mm) が小さく、 また座金の板厚 $(\mathrm{t}=4.5 \mathrm{~mm})$ が薄いので、金物周辺のめり込み応力度の 影響は少ないと考える。そのため、めり込み応力の状態を示す、図 
4 下の模式図に金物周辺部の応力度は描いていない。そこで、図 5 右の取り付けボルト軸の柱穴内面の作用応力は、繊維方向のめり込 み応力度 ${ }_{\mathrm{B}} \sigma_{1}$ と、羽子板ボルトの座金の梁繊維直交方向の接触面の めり込み応力度 $z_{z} \sigma_{1}$ は、図 4 下の模式図ように表せる。I（弾性域） では、まず、外力の引張りにより、柱の側面にボルトで取り付けら れる羽子板ボルトと柱心の偏心により、羽子板と柱側面の摩擦力が 生じる。その反作用の応力は、梁の羽子板ボルトの座金のめり込み 応力度 ${ }_{2} \sigma_{1}$ である。II (弾塑性域) では、図 5 右のような取り付け ボルト軸の曲げからロープ効果への挙動は、柱穴内面の繊維方向の 部分圧縮の三角形めり込み応力度 ${ }_{\mathrm{B}} \sigma_{1}{ }_{1}$ が生じ、さらに加力が進むと、 めり込み降伏応力度 ${ }_{\mathrm{B}} \sigma_{1 \mathrm{y}}$ になる。これは図 4 の荷重変位曲線の降 伏耐力 $\mathrm{P}_{\mathrm{y}}=7 \mathrm{kN}$ 、変位 $\delta_{\mathrm{y}}=1 \mathrm{~mm}$ 付近で折れ曲がる点である。 III（塑 性域)では座金のめり込み応力度 $z \sigma_{1}{ }_{1}$ が増加した最大值の降伏めり 込み応力度 $Z_{1 \text { y }}$ を示す。 IV (亀裂・割裂域) では金物の接触部で ひずみ硬化 $\max _{\operatorname{ma}} \sigma_{3}{ }_{\max } \sigma_{3}{ }_{3}$ が生じて破壊に至ると考える。破壊形 式は文献 9)によれば、取り付けボルトによる柱の繊維方向の割裂、 あるいは羽子板の切断である。羽子板ボルト仕口は、木部材の接触 面積である取り付けボルト軸側面積と座金の面積が、部材内蔵型金 物仕口の木部材と金物の接触面積よりも小さいために、部材内蔵型 金物仕口よりも負担できるめり込みの働きも小さい。

\section{c）部材内蔵型金物仕ロ及び羽子板ボルト仕口の接合部の比較}

表 4 に部材内蔵型金物仕口の接合部試験体と羽子板ボルト仕口の 接合部試験体の特徵を比較して示す。表 4 の部材内蔵型金物仕口と 羽子板ボルト仕口の全試験体を通した、破壞前の、塑性域内 $20 \mathrm{~mm}$ 変位時までのエネルギー吸収を、図 4 の荷重変位曲線より概算した。 部材内蔵型金物仕口の接合部の試験体は $570 \mathrm{kN} ・ \mathrm{~mm}$ であり、羽子板 ボルト仕口の接合部試験体は $291 \mathrm{kN} ・ \mathrm{~mm}$ である。部材内蔵型金物仕 口部のエネルギー吸収は、羽子板ボルト仕口の接合部試験体の約 2

表 4 部材内蔵型金物仕口の接合部試験体と羽子板ボルト仕口の 接合部試験体の特徽の比較

\begin{tabular}{|c|c|c|c|}
\hline & & 羽子板ボルト仕ロ & 部材内蔵型金物仕口 \\
\hline \multicolumn{2}{|c|}{ 接合部位 } & 柱+梁 & 柱+梁 \\
\hline \multicolumn{2}{|c|}{ 金物の部位 } & 部材の表面 & 部材内部 \\
\hline \multirow{4}{*}{\multicolumn{2}{|c|}{$\begin{array}{c}\text { 応力負担部品と } \\
\text { 負担応力 }\end{array}$}} & 座金のめり込み & 丸くさびCW12のめり込み \\
\hline & & 羽子板の引張り & 金棒 SH1248 の引張り \\
\hline & & 取付けボルトのめり込み & 棒ナット BN1275 のめり込み \\
\hline & & せん断力は柱のホゾによる & せん断力は柱のホゾによる \\
\hline \multicolumn{2}{|c|}{ 短期基準耐力 } & 7. $5 \mathrm{kN}$ & $14.6 \mathrm{kN}$ \\
\hline \multirow{2}{*}{$\begin{array}{c}\text { エネルギ } \\
\text { 一吸収 }\end{array}$} & $5 \mathrm{~mm}$ 変位時 & $42 \mathrm{kN} \cdot \mathrm{mm}$ & $91 \mathrm{kN} \cdot \mathrm{mm}$ \\
\hline & $20 \mathrm{~mm}$ 変位時 & $291 \mathrm{kN} \cdot \mathrm{mm}$ & $570 \mathrm{kN} \cdot \mathrm{mm}$ \\
\hline \multicolumn{2}{|c|}{ 破壊性状 } & 羽子板の切断 - 柱の割裂 & 柱の割裂・梁の引き裂け \\
\hline \multicolumn{2}{|c|}{ 弾性域での金物の効果 } & 金物周辺のめり込み応力小 & 金物周辺のめり込み応力大 \\
\hline \multicolumn{2}{|c|}{ 塑性域での金物の効果 } & ひずみ硬化小さい & ひずみ硬化大きい \\
\hline \multicolumn{2}{|c|}{ 破壊までの耐カ } & 耐力が維持できる。 & 耐力が高く維持される。 \\
\hline
\end{tabular}

倍になっている。また、弾塑性域内 $5 \mathrm{~mm}$ 変位時の、部材内蔵型金物 仕口の接合部による仕口の耐力は、 $20.6 \mathrm{kN}$ であり、エネルギー吸 収は $91 \mathrm{kN} ・ \mathrm{~mm}(=1 / 2 \times 20.6 \times 1.9+1 / 2 \times(20.6+25.5) \times(5-1.9))$ である。 羽子板ボルト仕口の接合部の耐力は $12 \mathrm{kN}$ であり、エネルギー吸収は $42 \mathrm{kN} \cdot \mathrm{mm}(=1 / 2 \times 2.1 \times 0.6+1 / 2 \times(12+6.6) \times(5-0.6))$ である。これも、 部材内蔵型金物仕口の接合部によるエネルギー吸収が 2 倍ほど上ま っている。このことから部材内蔵型金物による金物周辺のめり込み 応力と塑性ひずみのひずみ硬化の特性は、エネルギー吸収が大きく、
羽子板ボルトと同系の粘り強い復元力特性を示している。

\section{4. まとめ}

\section{(1) 部材内蔵型金物の特徵}

本金物は羽子板ボルトと同様に、柱-梁仕口、梁-梁仕口、梁-梁継 手など幅広い接合部に使用でき、在来の羽子板ボルトにはない以下 のような特徴がある。

1）接合部材の応力の偏心が起こりにくい。

2）部材に内蔵されるため、結露や熱橋が起こりにくい。

3）乾燥収縮やクリープによる部材の隙間を直すことができる。

4）部材加工は市販のドリルで加工ができて断面欠損も少ない。

\section{(2) 部材内蔵型金物仕口接合部の力学的特性}

梁柱接合部試験体について行った実験結果について以下にまとめ る。ただし、試験体寸法が羽子板ボルト仕口と部材内蔵型金物仕口 で異なるため、そのままでは比較できない。従って両仕口接合部の 力学特性の比較は、主として荷重変位曲線の形で行った。而力を比 較する時は後者の仕口寸法を前者のそれと合わせ補正を行っている。

1）部材内蔵型金物仕口の荷重変位曲線は、原点0から始まる。それ は部材内蔵型金物が木部材と緩みなく接触しているためである。

2）降伏前は部材内蔵型仕口の剛性が羽子板ボルト仕口よりも高い。

3）短期基準耐力は、部材内蔵型仕口の場合には14.6kNであり、羽 子板ボルト仕口の場合には $7.5 \mathrm{kN}$ である。

4）降伏後は部材内蔵型金物仕口の場合の変位は大きく増大し、耐 力もそれに伴い漸増する。これは部材内蔵型金物周辺のめり込 み応力と、塑性に伴うひずみ硬化特性の影響と考えられる。

これらから部材内蔵型金物は、木造軸組真壁構造の補強金物とし て、実用性が高いことが確認できた。

\section{謝辞}

本開発にあたり、性能実験を行った（財）日本建築総合試験所、 数々の開発実験を行って頂いた、関東職業能力開発大学校・岩田純 明研究室に感謝いたします。

\section{参考文献}

1）佐道健：木のメカニズム、養賢堂、 p. 77、p. 78、1995.7

2）岩田純明・宇都宮直樹：木質在来工法用接合金物、日本建築学会、大会 学術講演梗概集（東海）、22008、2003.9

3）（財）日本住宅・木材技術センター、木造軸組工法住宅の許容応力度設計 (2008 年版)、 p. $72 、$ p. $579 、$ p. $580 、$ p. 582,2008

4）建築技術、pp. 126（図 6）～127、1995.11

5）日本建築学会、木質構造設計基準 - 同解説（許容応力度 - 許容耐力設計 法)、pp. 26〜 33、2009. 3

6）杉山英男編著 : 木質構造第 4 版、共立出版、pp. 255～262、2012.3.15

7）日本建築学会、木質構造基礎理論 p. 41、pp. 86〜 103、2010. 12

8）棚橋秀光 - 大岡優 - 伊津野和行 - 鈴木祥之 : 木材のめり込み降伏メカニ ズムと均等めり込み弾塑性変位の定式化、日本建築学会、構造系論文集 第 76 巻第 662 号、 pp. 811 819、2011 年 4 月

9）後藤一雄 : 羽子板ボルト接合耐力の実験報告、日本建築学会、大会学術 講演梗概集（近畿）、2764、1980.9

[2015 年 6 月 3 日原稿受理 2015 年 7 月 21 日採用決定］ 